\title{
Effect of the Isocoumarin Paepalantine on the Luminol and Lucigenin Amplified Chemiluminescence of Rat Neutrophils
}

\author{
Rodrigo Rezende Kitagawa, ${ }^{a}$ Maria Stella Gonçalves Raddi, ${ }^{*}, b$ Najeh Maissar Khalit, ${ }^{b}$ \\ Wagner VILEgAS, ${ }^{a}$ and Luiz Marcos da FonSECA ${ }^{b}$ \\ a Instituto de Química de Araraquara, Universidade Estadual Paulista “Júlio de Mesquita Filho"; Rua Prof. Francisco \\ Degni, s/n, CP 355, 14801-970, Araraquara, SP, Brazil: and ${ }^{b}$ Faculdade de Ciências Farmacêuticas de Araraquara, \\ Universidade Estadual Paulista "Júlio de Mesquita Filho"; Rodovia Araraquara-Jaú, Km 1, 14801-902, Araraquara, SP, \\ Brazil. Received December 13, 2002; accepted February 12, 2003
}

\begin{abstract}
Paepalantine (9,10-dihydroxy-5,7-dimethoxy-1H-naphto(2,3c)pyran-1-one), a natural isocoumarin isolated from the capitula of Paepalanthus bromelioides (Eriocaulaceae), was assessed for its effect on the respiratory burst (zymosan-stimulated luminol-enhanced chemiluminescence and PMA-stimulated lucigenin-enhanced chemiluminescence) of polymorphonuclear neutrophils in vitro. Special attention was devoted to establishing the $\mathrm{IC}_{50}$ for neutrophils. Paepalantine was able to decrease luminol and lucigenin chemiluminescence, reflecting an inhibitory effect on the respiratory burst, with an $E_{50}$ of $0.44 \pm 0.05$ and $0.84 \pm 0.15 \mu \mathrm{g} / \mathrm{ml}$, respectively. A cellfree system was performed with paepalantine on myeloperoxidase $/ \mathrm{H}_{2} \mathrm{O}_{2}$ and myeloperoxidase $/ \mathrm{H}_{2} \mathrm{O}_{2} / \mathrm{Cl}^{-}$systems. Paepalantine inhibited luminol oxidation in both systems. This inhibition was related to the interaction of paepalantine-myeloperoxidase and its scavenger effect on HOCl.
\end{abstract}

Key words antioxidant activity; paepalantine; isocoumarin; chemiluminescence

The respiratory burst of phagocytes involves a striking increase in oxygen consumption, accompanied by activation of the hexose monophosphate shunt, which generates reactive oxygen species (ROS) including superoxide, hydrogen peroxide, hydroxy radicals and hypochlorous acid. The respiratory burst is triggered by the NADPH oxidase system, which is activated following the perturbation of the plasma membrane during phagocytosis or following the interaction between the cell surface and a variety of agents. ${ }^{1)}$

NADPH oxidase, a membrane multienzyme complex, catalyzes the univalent reduction of molecular oxygen by NADPH and generates $\mathrm{O}_{2}^{-}$. Subsequently, $\mathrm{H}_{2} \mathrm{O}_{2}$, which is also generated during the respiratory burst, is utilized by myeloperoxidase (MPO), an enzyme located in azurophil granules. MPO in the presence of a suitable halide ion such as $\mathrm{Cl}^{-}$produces hypochlorous acid $(\mathrm{HOCl}) .{ }^{2)}$ Neutrophil-derived oxidants (in particular $\mathrm{HOCl}$ ) react with a variety of different biological targets and can cause tissue damage. The ability of $\mathrm{HOCl}$ to damage proteins, amino acids, lipids and nucleic acids is thought to contribute to bacterial killing. ${ }^{3)}$

Neutrophils can defend themselves against the oxidant they produce through a variety of potent antioxidant systems. However, when produced in excess in the extracellular medium, oxidative species can damage host tissue. $\left.{ }^{4}\right)$ These reactive species are implicated in many diseases, including atherosclerosis, respiratory tract disorders, neurodegenerative diseases and cancer. ${ }^{5,6)}$ Therefore, controlling the respiratory burst may be useful for therapeutic intervention in many human diseases. ${ }^{7}$ )

Understanding of the biological activity of plant compounds has emerged during the last decade. Isocoumarins, secondary metabolites derived from the acetate pathway, have a wide range of activity, including: antitumoral, antileucemic, antiviral and antimicrobial. ${ }^{8-10)}$ We have reported on the activities of the isocoumarin paepalantine $(9,10$-dihydroxy-5,7-dimethoxy-1H-naphto(2,3c)pyran-1-one) (Fig. 1), including its cytotoxic effect, ${ }^{11)}$ mutagenic property ${ }^{12}$ and potential antimicrobial activity. ${ }^{13)}$ In continuation of our study on the biological activities of paepalantine, we evaluated its antioxidant potency by its interference in the respiratory burst of neutrophils and the $\mathrm{MPO} / \mathrm{H}_{2} \mathrm{O}_{2}$ system.

\section{RESULTS AND DISCUSSION}

A large number of techniques has been developed to monitor the generation and reduction of ROS by stimulated phagocytes during respiratory burst activity. As yet, no single technique is sufficient to determine the effects of different pharmacological agents affecting cellular responses. Chemiluminescence has been widely used as a sensitive and accurate method for assessing the capacity of neutrophils to produce ROS. ${ }^{14,15)}$ It is generally admitted that luminol is a relatively small molecule which is able to enter the cell and, therefore, reflects both extra and intracellular events. ${ }^{16)} \mathrm{Lu}-$ minol is oxidized by ROS generated during the respiratory burst, and luminol-enhanced chemiluminescence is dependent upon an MPO-mediated reaction, via peroxidative and chlorinating activity (generation of $\mathrm{HOCl}){ }^{17}$ ) The lucigenin chemiluminescence is generally attributed to extracellular $\mathrm{O}_{2}^{-}$. Being a larger molecule unable to enter in cells, lucigenin only reflects extracellular events. ${ }^{16)}$

For the present study, nonopsonized zymosan and PMA were selected from among the panel of existing activators, because our priority was to determine the active dose of paepalantine with good precision in a one-well standardized system. A significant inhibition of the intensity of luminol<smiles>COc1cc(O)c2c(O)c3c(=O)oc(C)cc3c(OC)c2c1</smiles>

Fig. 1. Chemical Structure of Paepalantine 


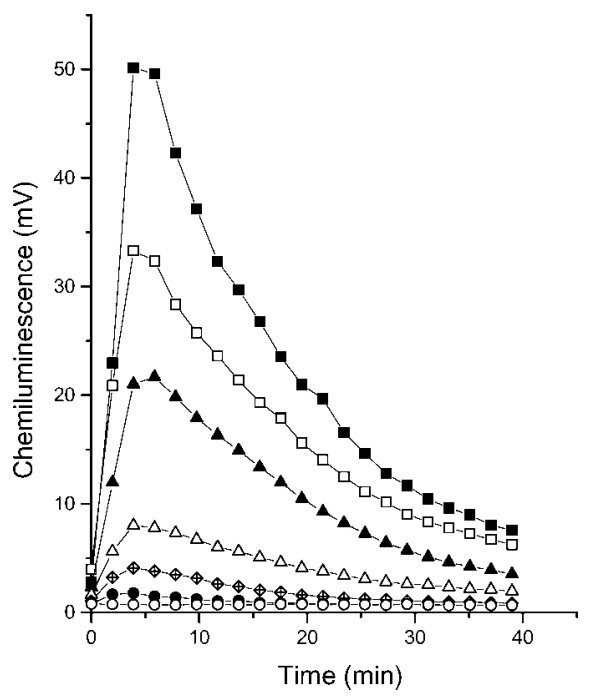

Fig. 2. Influence of Different Doses of Paepalantine on Non-Opsonized Zymosan-Induced Chemiluminescence of Polymorphonuclear Neutrophils

ROS production in neutrophils $\left(1.0 \times 10^{6} \mathrm{cell} / \mathrm{s} / \mathrm{ml}\right)$ is kinetically represented as millivolt $(\mathrm{mV})$ values detected by luminol enhanced chemiluminescence assay. ROS production in the cells treated with nonopsonized zymosan only, as the control (solid rectangle), or PBS-D only as the background (open circle) was measured during a period of 0 to $40 \mathrm{~min}$. The cells were treated with paepalantine at $0.12 \mu \mathrm{g} / \mathrm{ml}$ (open rectangle) $0.48 \mu \mathrm{g} / \mathrm{ml}$ (solid triangle), ${ }^{*} 0.98 \mu \mathrm{g} / \mathrm{ml}$ (open triangle), ${ }^{*} 1.98 \mu \mathrm{g} / \mathrm{ml}$ (cross diamond) ${ }^{*}$ and 3.9 and $7.8 \mu \mathrm{g} / \mathrm{ml}$ (solid circle). $* * p<0.05$

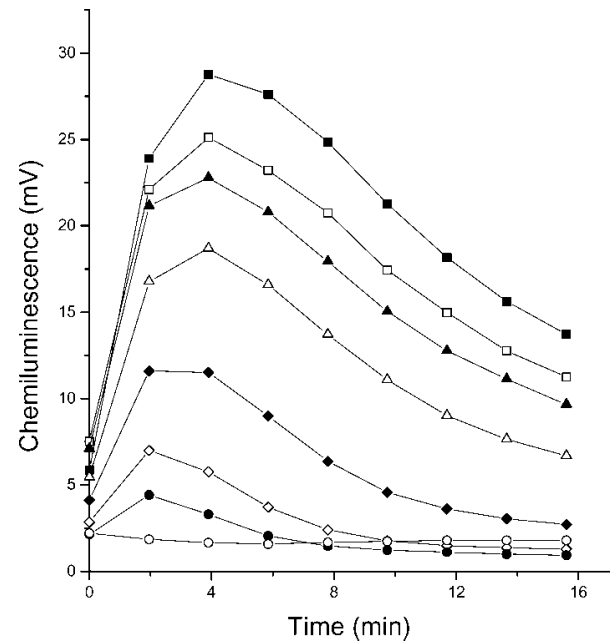

Fig. 3. Effect of Paepalantine on PMA-Stimulated Lucigenin-Enhanced Chemiluminescence of Polymorphonuclear Neutrophils

Superoxide production in the cells treated with PMA only, as the control (solid rectangle), or PBS-D only as the background (open circle) was measured during a period of 0 to $15 \mathrm{~min}$. The cells were treated with paepalantine at $0.12 \mu \mathrm{g} / \mathrm{ml}$ (open rectangle), $0.48 \mu \mathrm{g} / \mathrm{ml}$ (solid triangle), ${ }^{*} 0.98 \mu \mathrm{g} / \mathrm{ml}$ (open triangle), ${ }^{*} 1.98 \mu \mathrm{g} / \mathrm{ml}$ (solid diamond), ${ }^{*}$ 3.9 (open diamond) $*$ and $7.8 \mu \mathrm{g} / \mathrm{ml}$ (solid circle). $* * p<0.05$.

and lucigenin-enhanced chemiluminescence in stimulated neutrophils was observed (Figs. 2, 3). Our results showed that paepalantine is able to modulate the respiratory burst of phagocytes in a dose-dependent manner with $\mathrm{ED}_{50}$ of $0.44 \pm$ $0.05 \mu \mathrm{g} / \mathrm{ml}$ and $0.84 \pm 0.15 \mu \mathrm{g} / \mathrm{ml}$ for luminol and lucigeninenhanced chemiluminescence, respectively. This decrease in the luminol and lucigenin chemiluminescence is probably due to an inhibitory effect on some reactive oxygen generating systems, like the $\mathrm{MPO} / \mathrm{H}_{2} \mathrm{O}_{2} / \mathrm{Cl}^{-}$and/or the NADPH oxidase complex. Myeloperoxidase catalytic activity is complex and involves two distinct pathways (Fig. 4). Besides its regu-

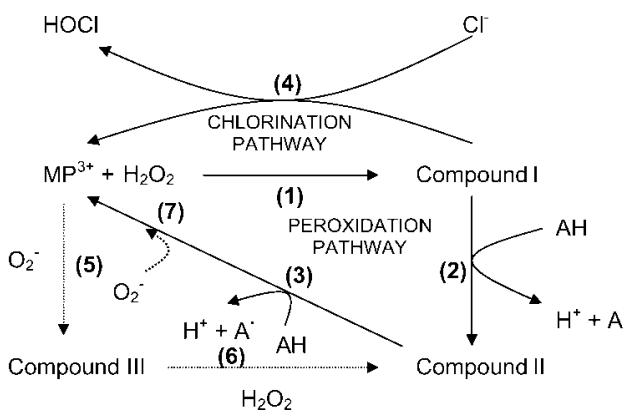

Fig. 4. Representation of Myeloperoxidase Catalytic Activity Pathways

$\mathrm{MP}^{3+}$ : native enzyme; Compound I: $\mathrm{MP}^{3+} \mathrm{H}_{2} \mathrm{O}_{2}$; Compound II: $\mathrm{MP}^{2+} \mathrm{H}_{2} \mathrm{O}_{2}$; Compound III: $\mathrm{MP}^{3+} \mathrm{O}_{2}$. $\mathrm{AH}$ : reducing substrate; $\mathrm{O}_{2}^{-}$: superoxide anion. The broken lines mean that the reaction is hypothetical under in vivo conditions (adapted from Nève et al., 2001).

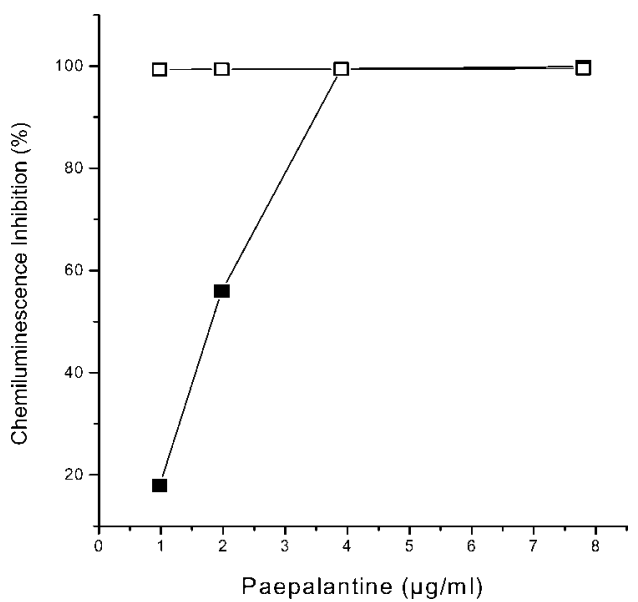

Fig. 5. Influence of Different Doses of Paepalantine on Luminol Amplified Chemiluminescence in a Cell-Free System

Chemiluminescence inhibition (\%) was calculated after incubation of paepalantine with $\mathrm{MPO} / \mathrm{H}_{2} \mathrm{O}_{2}$ (open rectangle) and $\mathrm{MPO} / \mathrm{H}_{2} \mathrm{O}_{2} / \mathrm{Cl}^{-}$(solid rectangle) systems in relation to the control. The addition of luminol on both systems without paepalantine (control) resulted in an immediate chemiluminescence response.

lar peroxidative activity (Fig. $4 ; 1-3$ ), myeloperoxidase has $\mathrm{HOCl}$ generation activity (Fig. $4 ; 1,4) .{ }^{18)}$ We investigated the effect of paepalantine on $\mathrm{MPO} / \mathrm{H}_{2} \mathrm{O}_{2}$ (peroxidative activity) and $\mathrm{MPO} / \mathrm{H}_{2} \mathrm{O}_{2} / \mathrm{Cl}^{-}$( $\mathrm{HOCl}$ generating activity). In both cellfree systems, paepalantine inhibited luminol oxidation (Fig. 5). The reduction of chemiluminescence by paepalantine is due to myeloperoxidase inhibition and a scavenging effect on HOCl. It seems that the inhibitory activity of the paepalantine on luminol-enhanced chemiluminescence from myeloperoxidase is a consequence of its interference with the enzymatic system rather than of scavenging activity. The scavenger effect of paepalantine on $\mathrm{HOCl}$ was confirmed by its ability to oxidize TNB test. The ability of $\mathrm{HOCl}$ to oxidize TNB resulted in a loss of absorbance at $412 \mathrm{~nm}$. Any $\mathrm{HOCl}$ scavenger present in the system will compete with TNB for $\mathrm{HOCl}$ and decrease the change in absorbance at 412 $\mathrm{nm} .{ }^{19)}$ Incubation of $\mathrm{HOCl}$ with paepalantine before the addition of TNB diminishes the amount of TNB to be oxidized, indicating that paepalantine reacts with $\mathrm{HOCl}$ (Table 1).

Although there is a wealth of data on the importance of antioxidants in conferring stability towards or protection from oxidation, the correlation between antioxidant activity and chemical structure is far from clear. ${ }^{20)}$ It is already well 
Table 1. Effect of Paepalantine on HOCl-Dependent TNB Oxidation

\begin{tabular}{cc}
\hline \hline Additions & $\mathrm{A} 412^{a)}$ \\
\hline No addition & 0.440 \\
Plus $\mathrm{HOCl}$ & 0.160 \\
$\mathrm{HOCl}$ and paepalantine & \\
$1.98 \mu \mathrm{g} / \mathrm{ml}$ & 0.388 \\
$3.9 \mu \mathrm{g} / \mathrm{ml}$ & 0.404 \\
$7.8 \mu \mathrm{g} / \mathrm{ml}$ & 0.408 \\
\hline
\end{tabular}

a) Values are the means from two independent measurements that varied by $5 \%$.

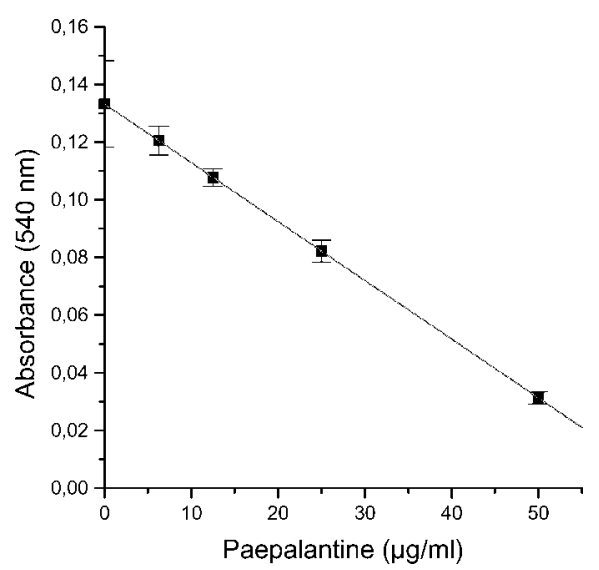

Fig. 6. Dose-Effect of Paepalantine on Neutrophils Performed by MTT Assay

Cells were seeded to 96-well microtitre plates at a concentration of $6 \times 10^{6}$ cells $/ \mathrm{ml}$ and treated with paepalantine, at different doses, for $24 \mathrm{~h}$. MTT was added to all wells, and plates were incubated at $37^{\circ} \mathrm{C}$. After $3 \mathrm{~h}$, the absorbance of the formazan was measured at $540 \mathrm{~nm}$ with $620 \mathrm{~nm}$ as a reference. Each point shows the mean \pm standard deviation of four experimental points.

established that flavonoids act as scavengers of various oxidizing species. The importance of the adjacency of the two hydroxyl groups (catechol) in the ortho-diphenolic arrangement of the B-ring of quercetin to its antioxidant activity is reported. $^{21)}$ The presence of $\mathrm{OH}-9$ and $\mathrm{OH}-10$ groups in paepalantine provides a catecholic-like system, and may allow the antioxidant activity of this isocoumarin as detected on $\mathrm{MPO} / \mathrm{H}_{2} \mathrm{O}_{2} / \mathrm{Cl}^{-}$system.

Many studies have been undertaken in lipophilic systems to establish the structural criteria for the activity of polyhydroxy phenolics in enhancing the stability of fatty acid dispersions, lipids and low density lipoproteins towards oxidation. ${ }^{20)}$ The specific mode of inhibition of oxidation by the individual polyphenols is not clear. The carbonyl at position 1 and the hydroxyl groups at positions 9 and 10 of paepalantine allow the formation of two strong intramolecular hydrogen bridges, making this molecule lipophilic, as has been previously verified by its high solubility in chloroform. ${ }^{13)}$

The cytotoxic midpoint $\left(\mathrm{IC}_{50}\right)$ of paepalantine against neutrophils using the MTT technique was $32.78 \pm 1.27 \mu \mathrm{g} / \mathrm{ml}$ (Fig. 6). However, there is a large difference in the dose dependency of neutrophil protective effects of paepalantine compared to its cytotoxic index. This raises an interesting issue when assessing antioxidant activities. A significant dose-dependent inhibition of the luminol-enhanced chemiluminescence was observed with paepalantine at almost an 80fold lower concentration than that obtained for $\mathrm{IC}_{50}$. Due to the difference in the toxic amount dose, consequences of biological effects on neutrophils may have a significant bearing on its therapeutic efficacy. It is clear from the foregoing that ROS produced from phagocytes are important in the pathogenesis of many conditions. The development of drugs to antagonize these oxidizing species may thus prevent at least some of the damage inflicted on tissues by these very reactive agents.

\section{EXPERIMENTAL}

Animal and Chemicals Male rats (Rattus albinus novegicus) with $190-200 \mathrm{~g}$ body weight and the folowing reagents were used: luminol (5-amino-2,3-dihydro-1,4-phthalazinedione) sodium salt (A4685), lucigenin (M8010), zymosan A (Z4250), PMA (P8139), glycogen type II from oyster (G8751), DMSO (D8779), RPMI (R7755) and MTTtetrazolium (M2128), all from Sigma Chemical Co. (U.S.A.); Ficoll-Paque Plus d 1077 (17-1440-02) from Pharmacia Biotech (Sweden). Paepalantine was obtained according to the procedure previously reported by Vilegas et al. (1990), and the stock solution was prepared at $10 \mathrm{mg} / \mathrm{ml}$ in DMSO. The highest absortion of paepalantine was at $265 \mathrm{~nm}$.

Peritoneal Neutrophils Collection Rats peritoneal neutrophils were obtained by the intraperitoneal injection of $10 \mathrm{ml}$ of oyster glycogen solution $0.5 \%(\mathrm{w} / \mathrm{v})$. Peritoneal exudate was collected $12 \mathrm{~h}$ later with Dulbecco's phosphatebuffered saline without calcium (PBS-D), containing $10 \mathrm{UI}$ heparin $/ \mathrm{ml}$. The cells were washed twice and carefully layered onto $5 \mathrm{ml}$ of Ficoll-Paque, and centrifuged for $30 \mathrm{~min}$ at $700 \boldsymbol{g}$. The neutrophils were washed twice in Dulbecco's phosphate-buffered saline (PBS) and adjusted to a concentration of $1.0 \times 10^{6}$ cells $/ \mathrm{ml}$. This procedure yields a preparation containing $95 \%$ neutrophils, and the control of their viability showed $98 \%$ of the cells, as judged by MTT-tetrazolium assay. $^{22,23)}$

Effect of Paepalantine on Viability of Neutrophils One hundred microlitres of RPMI containing approximately $6 \times 10^{6}$ cells $/ \mathrm{ml}$ were seeded into $96-w e l l$ tissue-culture plates and incubated at $37^{\circ} \mathrm{C}$. After $1 \mathrm{~h}$, the RPMI was removed and the cells were treated with paepalantine, in different doses, using PBS-D as a solvent. After $24 \mathrm{~h}$, the medium was removed and the plates were prepared for the MTT-tetrazolium assay. ${ }^{14,15)}$ After brief agitation, the plates were transferred to a microplate reader (Spectra \& Rainbow (Shell) Readers-Tecan, Austria), and the optical density of each well was measured using a $540 \mathrm{~nm}$ filter and a $620 \mathrm{~nm}$ reference wavelength. All experiments were performed at least four times, using three wells for each concentration of the chemical tested. The cytotoxicity data was standardized by determining absorbance and calculating the correspondent chemical concentrations. Linear regression analysis with $95 \%$ confidence limits was used to define dose-response curve and to compute the cytotoxic midpoint $\left(\mathrm{IC}_{50}\right)$, the concentration required to obtain a $50 \%$ decrease in the spectrophotometric absorbance as compared to the control. ${ }^{24)}$

Chemiluminescence Assay Chemiluminescence was measured on a BioOrbit model 1251 luminometer (Turku, Finland) using polypropylene tubes with a $1.0 \mathrm{ml}$ reaction mixture. Briefly, $1.0 \times 10^{6}$ cells $/ \mathrm{ml}$ of neutrophils, and $2 \times 10^{-5} \mathrm{M}$ luminol or $2 \times 10^{-5} \mathrm{M}$ lucigenin were added in tubes containing PBSD. After incubation for $10 \mathrm{~min}$ at $37^{\circ} \mathrm{C}$, $0.7 \mathrm{mg} / \mathrm{ml}$ nonopsonized zymosan or $3 \times 10^{-7} \mathrm{M}$ PMA and 
PBSD with paepalantine at non-cytotoxic concentrations $(0.12,0.48,0.98,1.98,3.9,7.8 \mu \mathrm{g} / \mathrm{ml})$ were mixed thoroughly. The background was measured without stimuli and paepalantine. The luminol and lucigenin-enhanced chemiluminescence was calculated by the software Multiuse 2.0. The chemiluminescence response was quantitated as an integrated area (IA) below the resulting chemiluminescence curve during a period of 0 to $40 \mathrm{~min}$ for luminol chemiluminescence and 0 to $15 \mathrm{~min}$ for lucigenin chemiluminescence. The values were compared to those of the control curve containing no paepalantine, i.e., cells/luminol or lucigenin/stimuli. The $\mathrm{ED}_{50}$, i.e., dose of paepalantine producing $50 \%$ inhibition of control chemiluminescence, was calculated using a $\log$-plot transformation of the data.

Effect of the Paepalantine on $\mathrm{MPO} / \mathrm{H}_{2} \mathrm{O}_{2}$ and MPO/ $\mathbf{H}_{2} \mathbf{O}_{2} / \mathbf{C l}^{-}$Reaction mixtures, including $\mathrm{PBS}-\mathrm{MgSO}_{4}$ (chloride-ion-free) or PBSD pH 7.4, $2 \times 10^{-5} \mathrm{M}$ luminol (final concentration), $75 \mathrm{mU}$ MPO and paepalantine at concentrations of $0.98,1.98,3.9$ and $7.8 \mu \mathrm{g} / \mathrm{ml}$, were mixed thoroughly. The assay was initiated by the addition of $\mathrm{H}_{2} \mathrm{O}_{2}$ $\left(5 \times 10^{-5} \mathrm{M}\right)$, and chemiluminescence was recorded for $10 \mathrm{~min}$. The values were compared with the control curve (systems without paepalantine), which was taken as $100 \%$ chemiluminescence.

Reactions with Hypochlorous Acid Reactions of $\mathrm{HOCl}$ were studied using the method of Ching et al., ${ }^{25)}$ based on the oxidation of 5-thio-2-nitrobenzoic acid (TNB). TNB was obtained by reducing a $1 \mathrm{~mm}$ solution of 5,5'dithiobis(2-nitrobenzoic acid) (DTNB) in a $50 \mathrm{~mm} \mathrm{KH}_{2} \mathrm{PO}_{4}-\mathrm{KOH}$ buffer, $\mathrm{pH}$ 6.6, containing $5 \mathrm{~mm}$ EDTA, and $20 \mathrm{~mm}$ sodium borohydride. For the assay, $25 \mu \mathrm{M} \mathrm{HOCl}$ was incubated with $50 \mu \mathrm{M}$ TNB for $5 \mathrm{~min}$ in the presence or absence of paepalantine in a final volume of $1 \mathrm{ml}$. The ability of the paepalantine to scavenge $\mathrm{HOCl}$ was determined by measuring the oxidation of TNB to DTNB at $412 \mathrm{~nm}$, preincubating the paepalantine with $\mathrm{HOCl}$, and then adding TNB.

Statistical Analysis The parameters were expressed as mean \pm standard deviation. Statistical analysis was performed with analysis of variance (ANOVA). Differences were considered significant at $p<0.05$.

Acknowledgements This study was supported by a grant of CNPq to RRK, a fellowship to WV, and financial assistance from the PADC-UNESP.

\section{REFERENCES}

1) Van Nerom A. E., Ducatelle R., Haesebrouck K., Dev. Comp. Immunol., 22, 407-416 (1998).

2) Capeillère-Blandin C., Biochem. J., 336, 395- 404 (1998).

3) Bergt C., Marsche G., Panzenboeck U., Heinecke J. W., Malle E., Sattler W., Eur. J. Biochem., 268, 3523-3531 (2001).

4) Labro M. T., Clin. Microbiol. Rev., 13, 615-650 (2000).

5) Anderson D., Phillips J., Food Chem. Toxicol., 37, 1015-1025 (1999).

6) Babior B. M., Am. J. Med., 109, 33-44 (2000).

7) Jang D. S., Kang B. S., Ryu S. Y., Chang I. M., Min K. R., Kim Y., Biochem. Pharmacol., 57, 705-712 (1999).

8) Hill R. A., Chem. Org. Naturst. Forschr., 49, 1-78 (1986).

9) Cañedo L. M., Puents J. L. F., Baz J. P., J. Antibiot., 50, 175-176 (1997).

10) Whyte A. C., Gloer J. B., Scott J. A., Malloch D., J. Nat. Prod., 59, 765-769 (1996).

11) Devienne K. F., Raddi M. S. G., Varanda E., Vilegas W., Z. Naturforsch. C, 57, 85-88 (2002).

12) Varanda E. A., Raddi M. S. G., Dias F. L., Araujo M. C. P., Gibran S. C. A., Takahashi C. S., Vilegas W., Terat. Car. Mutat., 17, 85-95 (1997).

13) Vilegas W., Roque N. F., Salantino A., Giesbrecht A. M., Davino S., Phytochemistry, 29, 2299-2301 (1990).

14) Dahlgren C., Karlsson A., J. Immun. Meth., 232, 3-14 (1999).

15) Liu Q., Suzuki K., Nakaji S., Sugawara K., Nutr. Res., 20, 5-14 (2000).

16) Parij N., Nagy A. M., Fondu P., Nève J., Eur. J. Pharmacol., 352, 299-305 (1998).

17) DeChatelet L. R., Long G. D., Shirley, P. S., Bass D. A., Thomas, M. J., Henderson F. W., Cohen M. S., J. Immunol., 129, 1589-1593 (1982).

18) Nève J., Parij N., Moguilevsky N., Euro. J. Pharmacol., 417, 37-43 (2001)

19) Marshall K. A., Reither R. J., Poeggeler B., Aruoma O. I., Halliwell B., Free Radic. Biol. Med., 21, 307-315 (1996).

20) Rice-Evans C. A., Miller N. J., Paganga G., Free Radic. Biol. Med., 20, 933-956 (1996).

21) Arora A., Nair M. G., Strasburg G. M., Free Radic. Biol. Med., 24, 1355-1363 (1998).

22) Freshney R. I., "Culture of Animal Cells: a Manual of Basic Technique," 3rd ed., Wiley-Liss, Inc., New York, 1994.

23) Mosmann T., J. Immun. Meth., 65, 55-63 (1983)

24) Barile F. A., "Introduction to in Vivo Cytotoxicology: Mechanisms and Methods," CRC Press, Boca Raton, 1994.

25) Ching T. L., Jong J., Bast A., Anal. Biochem., 218, 377-381 (1994). 